TAKING ON THE TRADITION 

Cultural Memory

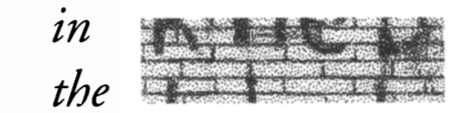

Present

Mieke Bal and Hent de Vries, Editors 



\section{TAKING ON THE TRADITION}

Jacques Derrida and the

Legacies of Deconstruction

Michael Naas

STANFORD UNIVERSITY PRESS

STANFORD, CALIFORNIA

2003 
Stanford University Press

Stanford, California

(C) 2003 by the Board of Trustees of the

Leland Stanford Junior University

All rights reserved.

Library of Congress Cataloging-in-Publication Data

Naas, Michael.

Taking on the tradition : Jacques Derrida and the legacies of deconstruction / Michael Naas.

p. cm.-(Cultural memory in the present)

ISBN 0-8047-442I-I (cloth : alk. paper) - ISBN 0-8047-4422-X (pbk. : alk. paper)

1. Derrida, Jacques. I. Title. II. Series.

B2430.D484 N33 2002

I94-dc2I

2002007736

Original Printing 2003

Last figure below indicates year of this printing:

$\begin{array}{lllllllll}\text { II } & \text { IO } & 09 & 08 & 07 & 06 & 05 & 04 & 03\end{array}$

Typeset by Classic Typography in II/13.5 Adobe Garamond. 
For Jean-Stéphane 
